\title{
Sustainability Reporting: A Paradigm for Stakeholder Conflict Management
}

\author{
Pius Vincent Chukwubuikem Okoye ${ }^{1}$, Francis Chinedu Egbunike ${ }^{1}$ \& Olamide Mofolusho Meduoye ${ }^{2}$ \\ ${ }^{1}$ Department of Accountancy, Nnamdi Azikiwe University, Awka, Nigeria \\ ${ }^{2}$ First Bank of Nigeria (FBN) Plc, Nigeria \\ Correspondence: Egbunike Francis Chinedu, Department of Accountancy, Nnamdi Azikiwe University, P.M.B. \\ 5025, Awka, Anambra State, Nigeria. Tel: 234-813-285-0409. E-mail: chineduegbunike@rocketmail.com
}

\author{
Received: March 10, $2013 \quad$ Accepted: April 6, $2013 \quad$ Online Published: April 17, 2013 \\ doi:10.5539/ibr.v6n5p157 URL: http://dx.doi.org/10.5539/ibr.v6n5p157
}

\begin{abstract}
This paper examined the nexus of corporate disclosure of environmental and social performance in form of sustainability reports on corporate stakeholder conflict management. Corporate stakeholder groups represent divergent interests in the activities of any corporation; as such, managing these interest groups is at the heart of survival for $21^{\text {st }}$ century corporations. The study is descriptive in nature and uses survey technique. The respondents comprised 121, made up of the following stakeholder groups: employees (38); managers (15); corporate accountants (18); shareholders (22) and 28 persons. The primary data were collected with the aid of a structured 5 point likert scale questionnaire. Three hypotheses were formulated and tested in the study. Descriptive statistics and Multiple Regression Technique were used in analyzing the primary data. Our empirical findings revealed that sustainability reporting would require managers to identify Key Social and Environmental performance indicators, this serves as a tool in understanding social and environmental stakeholder behavior. Respondents perceived that managing social and environmental stakeholder needs is crucial in sustaining a long-term relationship between management and these stakeholder groups. The link between the three constructs of sustainability was also identified, i.e. social and economic performance relationship; social and environmental performance relationship and environmental and economic performance relationship. Based on this, the study suggests the adoption of sustainability reporting practices by organizations; this however, should not precede the identification of key social and environmental performance indicators that would facilitate the integration of performance across the three dimensions into corporate core objectives and strategic values.
\end{abstract}

Keywords: economic stakeholder, environmental stakeholder, social stakeholder, TBLR

\section{Introduction}

The seminal work of R.E. Freeman (1984) who brought to limelight the need for a stakeholder approach to strategic management has become the thrust of management literatures in recent times, following the differing opinions of the concept as authors present views corresponding to their time period. The stronghold of this concept followed the criticism of classical economists' theory that corporate managers should not concern themselves with issues of social responsibility. Prominent factors such as: a growing awareness of the social and environmental impact of corporate manufacturing activities, the rise of the knowledge economy, and presence of 'vocal consumers' (Sani \& Allahverdizadeh, 2012) capable of using existing communication media to air product performance information, have demanded that managers refocus their attention to other performance areas previously neglected (Egbunike et al., 2012). As Osisioma (2010) observed a 'firm is not just a bundle of shares, rather a collection of relationships between owners, managers, employees, customers, suppliers and the society as a whole'. PriceWaterHouseCooper (PWC) (2011) stated that the quality of corporate responsibility data that corporations disclose will need to improve to meet up with stakeholder expectations. The report further noted that half of the CEO's recently surveyed by the firm planned to change the business strategies in the next three years because they expect stakeholders to factor in environmental and social issues into purchasing decisions.

Therefore, measuring corporate performance is likely to become more complex in the future as stakeholder expectations about companies' economic, social and environmental responsibilities change (Hubbard, 2006). Thus, corporate performance for $21^{\text {st }}$ century corporations requires the identification, measurement and inclusion of new performance metrics, reflecting a more diverse approach to corporate valuation against previous 
shareholder-based performance measures (Hubbard, 2006). This calls for modification of existing corporate management models to incorporate more diverse goals that firms are currently faced with (Herciu et al., 2011) so as to achieve long-term sustainable value for corporations (Osisioma, 2010).

Corporate sustainability that is the ability of a firm to carry out long-term operations depends on the sustainability of its stakeholder relations (Perrini \& Tencati, 2006) and meeting its triple bottom line performance dimensions (Fauzi et al., 2011). Kathy Nieland, PWC's US Sustainable Business Solutions Leader observed that:

'Investors, regulators and NGOs are holding businesses to higher standards; and company reputations and valuations are hanging on their ability to report on their efforts in a quantitative way' (PWC, 2011).

Thus, corporate responsibility redefined refers to engaging in continuous stakeholder dialogues in order to address various stakeholder needs from a holistic perspective and where sustainable corporate conduct is managed with economic, social and environmental values in mind (Mark-Herbert et al., 2010). The difficulty experienced by corporations in adopting a corporate sustainability plan is usually as a result of their chosen accounting system, as traditional management accounting systems fail to capture external costs (social and environmental costs). A corporate sustainability initiative can only be successfully implemented when corporations adopt systems capable of capturing social and environmental costs; which is a necessary starting point for the preparation of corporate sustainability reports. In this vein, a sustainability accounting framework and practice has been suggested by accounting bodies and scholars (IFAC, 2006; Petcharat \& Mula, 2010; Arroyo, 2008). The outcome of corporate sustainability accounting practice is usually the issuance of sustainability reports, as companies disclose performance across the three dimensions of sustainability: Economic, Social and Environmental performance areas (Elkington, 1998).

In the international scene, organizations and corporate bodies have started incorporating sustainability reports in their annual reports, with diverse variations in content and disclosure patterns. Prominent corporations include: British American Tobacco (BAT), China Mobile Communications Corporation, Central Textiles Group, MTR Corporation, CLP Holdings and Cathay Pacific Airways Limited, to name a few.

The broad objective of this study is to determine how social and environmental performance disclosures in form of corporate sustainability reports would help resolve issues of stakeholder management facing modern corporations. To tackle the specific objectives three stakeholder categories were identified following Egbunike et al. (2012) categorization, vis - environmental stakeholders, social stakeholders and economic stakeholders. More specifically, this study shall address the following research questions:

1) To what extent would social and environmental disclosure in form of corporate sustainability reports provide managers with strategies for managing economic stakeholders?

2) To what extent would social and environmental disclosure in form of corporate sustainability reports provide managers with strategies for managing environmental stakeholders?

3) To what extent would social and environmental disclosure in form of corporate sustainability reports provide managers with strategies for managing social stakeholders?

This paper is structured as follows: The first section reviews the path to present day sustainability issues; the second describes sustainability accounting and reporting in the context of present day corporations and its mode of preparation; and, the third, details stakeholder management related issues. Next is the research design, mode of primary data collection and analysis, the final sections details the summary of findings and recommendations.

\section{Literature Review}

\subsection{The Path to Sustainability}

Modern concerns about sustainable development emerged in the $60 \mathrm{~s} / 70 \mathrm{~s}$ with the release of several publications outlining global environmental, social issues and concerns (Tregidga et al., 2010). The first and foremost definition of the sustainability concept was offered by the Brundtland Commission of the United Nations in 1987 as 'meeting the needs of current generation without compromising the ability of future generations to meet their own needs'. The Commission further stated:

'Sustainable development is not a fixed state of harmony, but rather a process of change in which the exploitation of resources, the direction of investments, the orientation of technological development, and institutional change are made consistent with future as well as present needs'

Osisioma (2010) observed that the concept demands that a company's responsibility be to 'stakeholders' rather than shareholders, with the business entity used as a vehicle for coordinating stakeholder interest instead of maximizing shareholders' profit. From a corporate point of view, sustainability has been viewed as an integration 
of three performance aspects - economic, social and ecological systems (environment) - that companies require to sustain development (Dixon \& Fallon, 1989, cited in Petcharat \& Mula, 2010). Elkington (1998) the foremost runner of the triple bottom line catchphrase, stated that 'a sustainable enterprise is a firm that contributes to sustainable development by delivering simultaneously economic, social and environmental benefits'. The business case consists of asking how firms can enhance their economic sustainability by increasing their social and ecological efficiency (Arroyo, 2008). Elkington (1998) identified seven key drivers for organizations seeking sustainable development; these are presented in the table below:

Table 1. Key drivers of sustainability

\begin{tabular}{llll}
\hline $\mathbf{S} / \mathbf{N}$ & Drivers & Old paradigm & New Paradigm \\
\hline 1 & Markets & Compliance & Competition \\
2 & Values & Hard (economic figures) & Soft (additional values) \\
3 & Communication & Closed (internal) & Open (wider stakeholder analysis) \\
4 & Partnerships & Subvention & Symbiosis (win win) \\
5 & Life cycle technology & Focused on products & Focused on functions \\
6 & Time & Wide & Longer \\
7 & Corporate governance & Exclusive & Inclusive \\
\hline
\end{tabular}

Source: Elkington (1998).

\subsection{Sustainability Accounting \& Reporting}

Sustainability accounting and reporting can be defined as a subset of accounting and reporting that deals with activities, methods and systems to record, analyze and report:

Firstly: Environmentally and socially induced financial impacts.

Secondly: Ecological and social impacts of a defined economic system.

Thirdly: It deals with the measurement, analysis and communication of interactions and links between social, environmental and economic issues constituting the three dimensions of sustainability (Jasch \& Lavicka, 2005).

Sustainability accounting seeks to explore all three dimensions of sustainability (economic, social and environmental) by:

1) 'disaggregating the internal accounts to show costs and benefits relating to economic, social and environmental performance; and,

2) Extending the accounting boundary to consider the monetary value of external economic, social and environmental impacts' (Sigma project, 2003).

Constructing Excellence (2004) maintains that sustainability accounts can be used to:

1) Collect information on environmental and socially related expenditure and link them to financial benefits.

2) Show how environmental and social external costs can decline over time with commitment to sustainability.

3) Highlight the social and environmental risks associated with current financial performance and aid risk management.

4) Identify which stakeholder relationships present sustainability risks and benefits.

5) Encourage partnership between stakeholder organizations.

Jasch and Stasiskiene (2005) observed that companies' interest in sustainability accounting is closely related to sustainability reporting and the attempt to integrate the related requirements with existing information-, accounting - and management systems. The Global Reporting Initiative (GRI Sustainability Reporting Guidelines) (2011) defines sustainability reporting as ' $\ldots$ the practice of measuring, disclosing and being accountable to internal and external stakeholders for organizational performance towards the goal of sustainable development'.

The following factors were listed among others to be key drivers motivating corporations in disclosing sustainability report:

- To provide information about challenges and achievements to shareholders, employees, the public and other stakeholders;

- An internal commitment to environmental and social responsibility; 
- As a marketing tool, by associating the company with sound environmental management and sustainable activities;

- Tracking progress on integration of sustainability principles into company planning and programs;

- Taking first steps towards doing things in a more sustainable way; and,

- A commitment to remaining competitive while becoming a world leader in sustainability (source: http://www.sustreport.org/business/report/issues.html).

\subsection{Sustainability Reports Preparation}

According to Constructing Excellence (2004) it is usual to prepare two kinds of sustainability accounts to capture the direct financial impacts (costs and benefits) of sustainability initiatives on the organization as well as the indirect social and environmental impacts (evaluated in financial terms where possible) of the organization on third party stakeholders (such as the community and future generations), as shown below:

Direct Account (affecting the company)

Environmental / Social

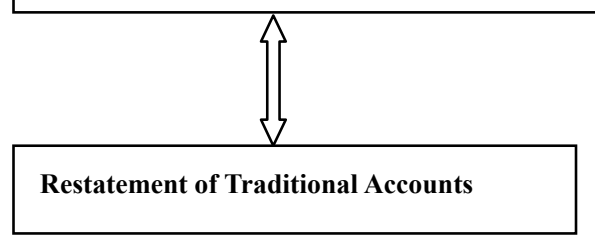

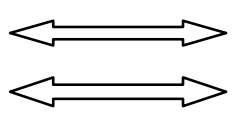

Environmental / Social

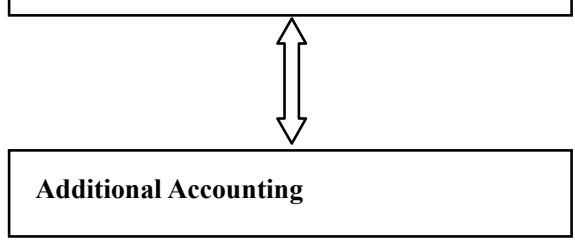

Figure 1. Two kinds of sustainability accounts

There are four steps in the preparation of the direct environmental and social accounts (Constructing Excellence, 2004):

1) Determination of the scope and boundary of the accounts

2) Identify all environmental and social features of the organization

3) Identify additional costs

4) Identify additional financial savings/benefits

Three steps were identified in the preparation of indirect cost accounts:

1) Scoping impacts

2) Determining boundaries

3) Monetary valuation of impacts

\subsection{Stakeholder Management}

The diversity in stakeholder definition and classification stems from the varying contextual applications of the term in the literatures. Freeman (1984) defined corporate stakeholders as 'any group or individual who can affect or is affected by, the achievement of a corporation's purpose'. Corporate stakeholders are broadly divided into two: internal and external. Internal stakeholders are actors in the business organization (Egbunike et al., 2012). Examples include: employees, corporate proprietors and managers. External stakeholders are actors outside the business (Egbunike et al., 2012). Examples include: tax authorities, government, customers and competitors. The thrust of stakeholder theory is to assess organizational performance against the expectations of varying stakeholder groups that have unique identifiable interest in the operations and activities of the organization. 


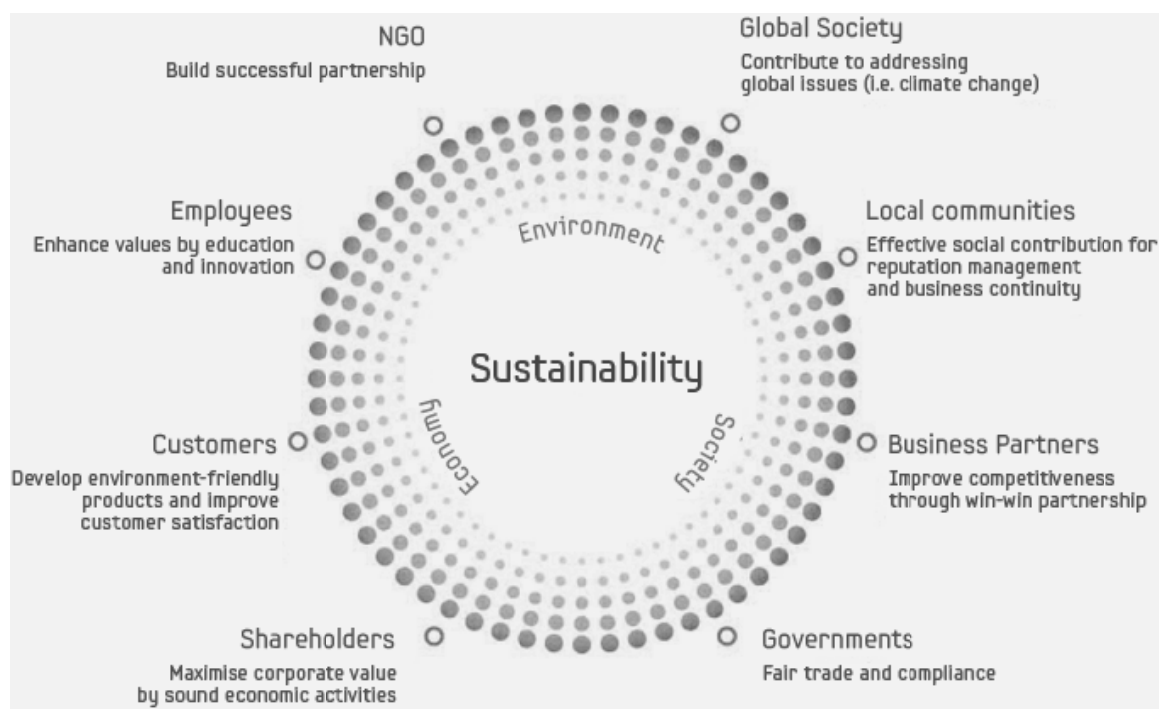

Figure 2 . The link between corporate stakeholder management and sustainability

Source: www.samsung.com

\section{Research Design}

The descriptive research design was adopted for this study, with the choice of its exploratory technique. The questionnaire was structured on a five point likert scale with the following options: Strongly Agree (SA); Agree (A); Indifferent (ID); Disagree (D); Strongly Disagree (SD) with the associated weights of 5,4,3,2 and 1 respectively. Respondents were divided into two groups: Internal stakeholders comprising employees (38), managers (15) and corporate accountants (18); External stakeholders comprising shareholders (22) and persons not included in the first categorization (28) distributed across two zones, Awka and Onitsha. Three hypotheses were formulated and analyzed using Multiple Regression Technique.

\section{Results}

\subsection{Presenting the Results of Hypothesis One}

$\mathrm{H}_{1}$ : Social and environmental disclosure in form of corporate sustainability reportswould not provide managers with strategies for managing economic stakeholders.

Table 2. Frequency distribution of questions 1 - 5

\begin{tabular}{|c|c|c|c|c|c|c|c|}
\hline $\mathrm{S} / \mathrm{No}$ & Question Description & SA & $\mathrm{A}$ & ID & $\mathrm{D}$ & SD & $\begin{array}{l}\text { Mean } \\
\text { Score }\end{array}$ \\
\hline 1 & $\begin{array}{l}\text { Economic performance information is crucial in judging } \\
\text { the growth and performance of a corporation by both } \\
\text { internal and external stakeholders }\end{array}$ & $\begin{array}{l}85 \\
(70.2 \%)\end{array}$ & $\begin{array}{l}17 \\
(14 \%)\end{array}$ & $\begin{array}{l}10 \\
(8.3 \%)\end{array}$ & $\begin{array}{l}8 \\
(6.6 \%)\end{array}$ & $\begin{array}{l}1 \\
(.8 \%)\end{array}$ & 4.4628 \\
\hline 2 & $\begin{array}{l}\text { Managing economic stakeholder needs is crucial in } \\
\text { sustaining a long-term relationship between management } \\
\text { and economic stakeholders }\end{array}$ & $\begin{array}{l}90 \\
(74.4 \%)\end{array}$ & $\begin{array}{l}18 \\
(14.9 \%)\end{array}$ & $\begin{array}{l}8 \\
(6.6 \%)\end{array}$ & $\begin{array}{l}4 \\
(3.3 \%)\end{array}$ & $\begin{array}{l}1 \\
(.8 \%)\end{array}$ & 4.5868 \\
\hline 3 & $\begin{array}{l}\text { Full disclosure of economic related performance areas } \\
\text { would improve likelihood of trust among investors, as } \\
\text { investors consider economic information in making } \\
\text { investment decisions }\end{array}$ & $\begin{array}{l}69 \\
(57 \%)\end{array}$ & $\begin{array}{l}22 \\
(18.2 \%)\end{array}$ & $\begin{array}{l}16 \\
(13.2 \%)\end{array}$ & $\begin{array}{l}8 \\
(6.6 \%)\end{array}$ & $\begin{array}{l}6 \\
(5 \%)\end{array}$ & 4.1570 \\
\hline 4 & $\begin{array}{l}\text { There is a direct link between social and economic } \\
\text { performance as such positive social disclosure would } \\
\text { likely improve economic performance }\end{array}$ & $\begin{array}{l}79 \\
(65.3 \%)\end{array}$ & $\begin{array}{l}2 \\
(1.7 \%)\end{array}$ & $\begin{array}{l}26 \\
(21.5 \%)\end{array}$ & $\begin{array}{l}10 \\
(8.3 \%)\end{array}$ & $\begin{array}{l}4 \\
(3.3 \%)\end{array}$ & 4.1736 \\
\hline 5 & $\begin{array}{l}\text { There is a direct link between environmental and } \\
\text { economic performance as such positive environmental } \\
\text { disclosure would likely improve economic performance }\end{array}$ & $\begin{array}{l}69 \\
(57 \%)\end{array}$ & $\begin{array}{l}8 \\
(6.6 \%)\end{array}$ & $\begin{array}{l}18 \\
(14.9 \%)\end{array}$ & $\begin{array}{l}20 \\
(16.5 \%)\end{array}$ & $\begin{array}{l}6 \\
(5 \%)\end{array}$ & 3.9421 \\
\hline
\end{tabular}

Source: Field Survey (2013). 


\subsubsection{Fitting the Hypothesis Regression Function}

$\mathrm{Y}($ Economic Stakeholder Management $)=\alpha+\beta \mathrm{X}_{1}$ (Full Disclosure of Economic Related Performance Areas $)+$ $\beta X_{2}$ (Social and Economic Performance Link) $+\beta X_{3}$ (Environmental and Economic Performance Link) $+e_{i}$

Table 3. Model summary table for hypothesis one

\begin{tabular}{lllll}
\hline Model & $\mathrm{R}$ & R Square & Adjusted R Square & Std. Error of the Estimate \\
\hline 1 & $.498^{\mathrm{a}}$ & .248 & .229 & .72287 \\
\hline
\end{tabular}

Note: a. Predictors: (Constant), VAR00005, VAR00003, VAR00004

Source: SPSS Version 17

Table 4. Coefficients table for hypothesis one

\begin{tabular}{lllllll}
\hline \multirow{2}{*}{ Model } & \multicolumn{2}{l}{ Unstandardized Coefficients } & Standardized Coefficients & \multirow{2}{*}{ Sig. } \\
\cline { 2 - 5 } & $\mathrm{B}$ & Std. Error & Beta & & \\
\hline 1 & (Constant) & 2.811 & .297 & & 9.448 & .000 \\
& VAR00003 & .235 & .062 & .338 & 3.821 & .000 \\
& VAR00004 & .111 & .061 & .164 & 1.837 & .069 \\
& VAR00005 & .085 & .053 & .140 & 1.587 & .115 \\
\hline
\end{tabular}

Note: a. Dependent Variable: VAR00002.

Source: SPSS Version 17.

Table 5. ANOVA table for hypothesis one

\begin{tabular}{|c|c|c|c|c|c|c|}
\hline \multicolumn{2}{|c|}{ Model } & \multirow{2}{*}{$\frac{\text { Sum of Squares }}{20.202}$} & \multirow{2}{*}{$\frac{\mathrm{df}}{3}$} & \multirow{2}{*}{$\begin{array}{l}\text { Mean Square } \\
6.734\end{array}$} & \multirow{2}{*}{$\frac{F}{12.887}$} & \multirow{2}{*}{$\begin{array}{l}\text { Sig. } \\
.000^{\mathrm{a}}\end{array}$} \\
\hline 1 & Regression & & & & & \\
\hline & Residual & 61.137 & 117 & .523 & & \\
\hline & Total & 81.339 & 120 & & & \\
\hline
\end{tabular}

Notes: a. Predictors: (Constant), VAR00005, VAR00003, VAR00004; b. Dependent Variable: VAR00002.

\subsubsection{Evaluating the Model Coefficients}

From the Standardized Coefficients Column (Beta):- Full Disclosure of Economic Related Performance Areas had the greatest Beta value of .338 and Sig. $(.000<.05)$ and therefore is the most significant predictor variable; variables $\mathrm{X}_{2}$ (Social and Economic Performance Link) and $\mathrm{X}_{3}$ (Environmental and Economic Performance Link) all had Sig. values greater than .05. R-square had a value of .248 and adjusted R-square value is .229 (approximately 23\% percent of the dependent variable were explained by the independent variables). The low $\mathrm{R}$-squared value indicates the presence of other factors (not considered by the presnt study) that could explain economic stakeholder management.

\subsubsection{Decision Rule}

Using the ANOVA table, which tests the acceptability of the model from a statistical perspective, the decision rule is as follows if $F_{\text {computed }}>F_{\text {table value }}$ - reject the null hypothesis; otherwise accept. Since $12.887>2.60$, the null hypothesis is rejected and the alternate accepted. Thus, Social and environmental disclosure in form of corporate sustainability reports would provide managers with strategies for managing economic stakeholders. This decision is strengthened by the fact that the significant value of F statistics $(0.000)$ is less than 0.05 , which means that the variation explained by the model is not due to chance.

\subsection{Presenting the Results of Hypothesis Two}

$\mathrm{HO}_{2}$ : Social and environmental disclosure in form of corporate sustainability reportswould not provide managers with strategies for managing environmental stakeholders. 
Table 6. Frequency distribution of questions 6 - 10

\begin{tabular}{|c|c|c|c|c|c|c|}
\hline S/No & Question Description & SA & A & ID & $\mathrm{D}$ & SD \\
\hline 6 & $\begin{array}{l}\text { Sustainability reporting practice would require managers to identify Key } \\
\text { Environmental Performance indicators, which serve as a tool for } \\
\text { understanding environmental stakeholder behavior }\end{array}$ & $\begin{array}{l}71 \\
(58.7 \%)\end{array}$ & $\begin{array}{l}8 \\
(6.6 \%)\end{array}$ & $\begin{array}{l}8 \\
(6.6 \%)\end{array}$ & $\begin{array}{l}14 \\
(11.6 \%)\end{array}$ & $\begin{array}{l}20 \\
(16.5 \%)\end{array}$ \\
\hline 7 & $\begin{array}{l}\text { Managing environmental stakeholder needs is crucial in sustaining a } \\
\text { long-term relationship between management and environmental } \\
\text { stakeholders }\end{array}$ & $\begin{array}{l}68 \\
(56.2 \%)\end{array}$ & $\begin{array}{l}18 \\
(14.9 \%)\end{array}$ & $\begin{array}{l}6 \\
(5 \%)\end{array}$ & $\begin{array}{l}17 \\
(14 \%)\end{array}$ & $\begin{array}{l}12 \\
(9.9 \%)\end{array}$ \\
\hline 8 & $\begin{array}{l}\text { Full disclosure of environmental related performance areas would } \\
\text { improve likelihood of trust among investors, as 'environmentally friendly' } \\
\text { investors consider environmental information in making investment } \\
\text { decisions }\end{array}$ & $\begin{array}{l}57 \\
(47.1 \%)\end{array}$ & $\begin{array}{l}23 \\
(19 \%)\end{array}$ & $\begin{array}{l}2 \\
(1.7 \%)\end{array}$ & $\begin{array}{l}27 \\
(22.3 \%)\end{array}$ & $\begin{array}{l}12 \\
(9.9 \%)\end{array}$ \\
\hline 9 & $\begin{array}{l}\text { There is a direct link between social and environmental performance as } \\
\text { such positive social disclosure would likely improve environmental } \\
\text { performance }\end{array}$ & $\begin{array}{l}66 \\
(54.5 \%)\end{array}$ & $\begin{array}{l}26 \\
(21.5 \%)\end{array}$ & $\begin{array}{l}3 \\
(2.5 \%)\end{array}$ & $\begin{array}{l}26 \\
(21.5 \%)\end{array}$ & 0 \\
\hline 10 & $\begin{array}{l}\text { There is a direct link between economic and environmental performance } \\
\text { as such positive economic disclosure would likely improve environmental } \\
\text { performance }\end{array}$ & $\begin{array}{l}52 \\
(43 \%)\end{array}$ & $\begin{array}{l}42 \\
(34.7 \%)\end{array}$ & $\begin{array}{l}22 \\
(18.2 \%)\end{array}$ & $\begin{array}{l}3 \\
(2.5 \%)\end{array}$ & $\begin{array}{l}2 \\
(1.7 \%)\end{array}$ \\
\hline
\end{tabular}

Source: Field Survey (2013)

\subsubsection{Fitting the Hypothesis Regression Function}

$\mathrm{Y}($ Key Environmental Performance Indicators $)=\alpha+\beta \mathrm{X}_{1}$ (Environmental Stakeholder Management $)+\beta \mathrm{X}_{2}$ (Full Disclosure of Environmental Related Performance Areas) $+\beta X_{3}$ (Social and Environmental Performance Link $)+\beta \mathrm{X}_{4}($ Economic and Environmental Performance Link $)+\mathrm{e}_{\mathrm{i}}$

Table 7. Model summary table for hypothesis two

\begin{tabular}{lllll}
\hline Model & $\mathrm{R}$ & R Square & Adjusted R Square & Std. Error of the Estimate \\
\hline 1 & $.632^{\mathrm{a}}$ & .399 & .378 & 1.26720 \\
\hline
\end{tabular}

Note: a. Predictors: (Constant), VAR00010, VAR00007, VAR00008, VAR00009.

Source: SPSS Version 17

Table 8. Coefficients table for hypothesis two

\begin{tabular}{|c|c|c|c|c|c|c|}
\hline \multirow{2}{*}{\multicolumn{2}{|c|}{ Model }} & \multicolumn{2}{|c|}{ Unstandardized Coefficients } & \multirow{2}{*}{$\begin{array}{l}\text { Standardized Coefficients } \\
\text { Beta }\end{array}$} & \multirow[t]{2}{*}{$\mathrm{t}$} & \multirow[t]{2}{*}{ Sig. } \\
\hline & & $\mathrm{B}$ & Std. Error & & & \\
\hline \multirow[t]{5}{*}{1} & (Constant) & .969 & .851 & & 1.139 & .257 \\
\hline & VAR00007 & .691 & .082 & .620 & 8.451 & .000 \\
\hline & VAR00008 & .124 & .091 & .115 & 1.357 & .177 \\
\hline & VAR00009 & -.148 & .117 & -.111 & -1.272 & .206 \\
\hline & VAR00010 & .061 & .132 & .035 & .462 & .645 \\
\hline
\end{tabular}

a. Dependent Variable: VAR00006.

Source: SPSS Version 17.

Table 9. ANOVA table for hypothesis two

\begin{tabular}{lllllll}
\hline Model & & Sum of Squares & df & Mean Square & F & Sig. \\
\hline 1 & Regression & 123.562 & 4 & 30.890 & 19.237 & $.000^{\mathrm{a}}$ \\
& Residual & 186.273 & 116 & 1.606 & & \\
& Total & 309.835 & 120 & & & \\
\hline
\end{tabular}

Note: a. Predictors: (Constant), VAR00010, VAR00007, VAR00008, VAR00009. 


\subsubsection{Evaluating the Model Coefficients}

From the Standardized Coefficients Column (Beta):- Environmental Stakeholder Management had the greatest Beta value of .620 and Sig. $(.000<.05)$ and therefore is the most significant predictor variable; variables $\mathrm{X}_{2}$ (Full Disclosure of Environmental Related Performance Areas), $X_{3}$ (Social and Environmental Performance Link) and $\mathrm{X}_{4}$ (Economic and Environmental Performance Link) all had Sig. values greater than .05. R-square had a value of .399 and adjusted R-square value is .378 (approximately $38 \%$ percent of the dependent variable were explained by the independent variables). The low R-squared value indicates the presence of other factors (not considered by the present study) that could explain environmental stakeholder management.

\subsubsection{Decision Rule}

Using the ANOVA table, which tests the acceptability of the model from a statistical perspective, the decision rule is as follows if $F_{\text {computed }}>F_{\text {table value }}$ - reject the null hypothesis; otherwise accept. Since $19.237>2.45$, the null hypothesis is rejected and the alternate accepted. Thus, Social and environmental disclosure in form of corporate sustainability reports would provide managers with strategies for managing environmental stakeholders. This decision is strengthened by the fact that the significant value of F statistics $(0.000)$ is less than 0.05 .

\subsection{Presenting the Results of Hypothesis Three}

$\mathrm{HO}_{3}$ : Social and environmental disclosure in form of corporate sustainability reportswould not provide managers with strategies for managing social stakeholders

Table 10. Frequency distribution of questions $11-15$

\begin{tabular}{|c|c|c|c|c|c|c|c|}
\hline $\mathrm{S} / \mathrm{No}$ & Question Description & SA & A & ID & $\mathrm{D}$ & SD & $\begin{array}{l}\text { Mean } \\
\text { Score }\end{array}$ \\
\hline 11 & $\begin{array}{l}\text { Sustainability reporting practice would require managers to } \\
\text { identify Key Social Performance indicators, which serve as a } \\
\text { tool for understanding social stakeholder behavior }\end{array}$ & $\begin{array}{l}58 \\
(47.9 \%)\end{array}$ & $\begin{array}{l}36 \\
(29.8 \%)\end{array}$ & $\begin{array}{l}16 \\
(13.2 \%)\end{array}$ & $\begin{array}{l}1 \\
(0.8 \%)\end{array}$ & $\begin{array}{l}10 \\
(8.3 \%)\end{array}$ & 4.0826 \\
\hline 12 & $\begin{array}{l}\text { Managing social stakeholder needs is crucial in sustaining a } \\
\text { long-term relationship between management and social } \\
\text { stakeholders }\end{array}$ & $\begin{array}{l}91 \\
(75.2 \%)\end{array}$ & $\begin{array}{l}18 \\
(14.9 \%)\end{array}$ & $\begin{array}{l}8 \\
(6.6 \%)\end{array}$ & $\begin{array}{l}2 \\
(1.7 \%)\end{array}$ & $2(1.7 \%)$ & 4.6033 \\
\hline 13 & $\begin{array}{l}\text { Full disclosure of social related performance areas would } \\
\text { improve likelihood of trust among investors, as 'socially } \\
\text { responsible' investors consider social information in making } \\
\text { investment decisions }\end{array}$ & $\begin{array}{l}61 \\
(50.4 \%)\end{array}$ & $\begin{array}{l}28 \\
(23.1 \%)\end{array}$ & $\begin{array}{l}16 \\
(13.2 \%)\end{array}$ & $\begin{array}{l}4 \\
(3.3 \%)\end{array}$ & $\begin{array}{l}12 \\
(9.9 \%)\end{array}$ & 4.0083 \\
\hline 14 & $\begin{array}{l}\text { There is a direct link between environmental and social } \\
\text { performance as such positive environmental disclosure } \\
\text { would likely improve social performance }\end{array}$ & $\begin{array}{l}75 \\
(62.0 \%)\end{array}$ & $\begin{array}{l}2 \\
(1.7 \%)\end{array}$ & $\begin{array}{l}26 \\
(21.5 \%)\end{array}$ & $\begin{array}{l}5 \\
(4.1 \%)\end{array}$ & $\begin{array}{l}13 \\
(10.7 \%)\end{array}$ & 4.0000 \\
\hline 15 & $\begin{array}{l}\text { There is a direct link between economic and social } \\
\text { performance as such positive economic disclosure would } \\
\text { likely improve social performance }\end{array}$ & $\begin{array}{l}56 \\
(46.3 \%)\end{array}$ & $\begin{array}{l}32 \\
(26.4 \%)\end{array}$ & $\begin{array}{l}21 \\
(17.4 \%)\end{array}$ & $\begin{array}{l}4 \\
(3.3 \%)\end{array}$ & $\begin{array}{l}8 \\
(6.6 \%)\end{array}$ & 4.0248 \\
\hline
\end{tabular}

Source: Field Survey (2013).

\subsubsection{Fitting the Hypothesis Regression Function}

$Y($ Key Social Performance Indicators $)=\alpha+\beta X_{1}$ (Social Stakeholder Management) $+\beta X_{2}$ (Full Disclosure of Social Related Performance Areas) $+\beta X_{3}$ (Environmental and Social Performance Link) $+\beta X_{4}$ (Economic and Social Performance Link) $+e_{i}$

Table 11. Model summary table for hypothesis three

\begin{tabular}{lllll}
\hline Model & $\mathrm{R}$ & R Square & Adjusted R Square & Std. Error of the Estimate \\
\hline 1 & $.794^{\mathrm{a}}$ & .630 & .617 & .73027 \\
\hline
\end{tabular}

Note: a. Predictors: (Constant), VAR00015, VAR00012, VAR00014, VAR00013.

Source: SPSS Version 17. 
Table 12. Coefficients table for hypothesis three

\begin{tabular}{|c|c|c|c|c|c|c|}
\hline \multirow{2}{*}{\multicolumn{2}{|c|}{ Model }} & \multicolumn{2}{|c|}{ Unstandardized Coefficients } & \multirow{2}{*}{$\begin{array}{l}\text { Standardized Coefficients } \\
\text { Beta }\end{array}$} & \multirow[t]{2}{*}{$\mathrm{t}$} & \multirow[t]{2}{*}{ Sig. } \\
\hline & & $\mathrm{B}$ & Std. Error & & & \\
\hline \multirow[t]{5}{*}{1} & (Constant) & 1.190 & .454 & & 2.621 & .010 \\
\hline & VAR00012 & .151 & .087 & .105 & 1.740 & .085 \\
\hline & VAR00013 & -.148 & .061 & -.163 & -2.449 & .016 \\
\hline & VAR00014 & -.116 & .051 & -.138 & -2.254 & .026 \\
\hline & VAR00015 & .809 & .059 & .804 & 13.814 & .000 \\
\hline
\end{tabular}

Note: a. Dependent Variable: VAR00011.

Source: SPSS Version 17.

Table 13. ANOVA table for hypothesis three

\begin{tabular}{|c|c|c|c|c|c|c|}
\hline \multicolumn{2}{|c|}{ Model } & \multirow{2}{*}{$\frac{\text { Sum of Squares }}{105.312}$} & \multirow{2}{*}{$\frac{\mathrm{df}}{4}$} & \multirow{2}{*}{$\frac{\text { Mean Square }}{26.328}$} & \multirow{2}{*}{$\frac{F}{49.369}$} & \multirow{2}{*}{$\begin{array}{l}\text { Sig. } \\
.000^{\mathrm{a}}\end{array}$} \\
\hline 1 & Regression & & & & & \\
\hline & Residual & 61.862 & 116 & .533 & & \\
\hline & Total & 167.174 & 120 & & & \\
\hline
\end{tabular}

Notes: a. Predictors: (Constant), VAR00015, VAR00012, VAR00014, VAR00013; b. Dependent Variable: VAR00011.

Source: SPSS Version 17.

\subsubsection{Evaluating the Model Coefficients}

From the Standardized Coefficients Column (Beta):- Economic and Social Performance Link had the greatest Beta value of .804 and Sig. $(.000<.05)$ and therefore is the most significant predictor variable; variables $\mathrm{X}_{2}$ (Full Disclosure of Social Related Performance Areas) and $\mathrm{X}_{3}$ (Environmental and Social Performance Link) all had Sig. values less than .05 , while only variable $\mathrm{X}_{1}$ (Social Stakeholder Management) had a Sig. values greater than .05. R-square had a value of .630 and adjusted R-square value is .617 (approximately $62 \%$ percent of the dependent variable were explained by the independent variables).

\subsubsection{Decision Rule}

Using the ANOVA table, which tests the acceptability of the model from a statistical perspective, the decision rule is as follows if $F_{\text {computed }}>F_{\text {table value }}$ - reject the null hypothesis; otherwise accept. Since $49.369>2.45$, the null hypothesis is rejected and the alternate accepted. Thus, Social and environmental disclosure in form of corporate sustainability reports would provide managers with strategies for managing social stakeholders. This decision is strengthened by the fact that the significant value of F statistics $(0.000)$ is less than 0.05 .

\section{Summary of Findings}

Sustainability has dominated management philosophy of $21^{\text {st }}$ century corporations, as managers strive to meet performance across its three dimensions usually showcased in the form of sustainability reports. However the contents vary across industries, business organizations and nations. In recent times studies have therefore attempted to examine the connection between the practice and $21^{\text {st }}$ century management. The results of our empirical data analysis revealed the following:

1) Sustainability reporting practice would require managers to identify Key Social and Environmental Performance indicators, these KPIs serve as tools for understanding social and environmental stakeholder behavior;

2) Respondents perceived that managing social and environmental stakeholder needs is crucial in sustaining a long-term relationship between management and these stakeholder groups;

3) Full disclosure of social and environmental related performance areas would improve trust among investors, as socially and environmentally responsible investors consider social and environmental information in making investment decisions;

4) The results of the study also indicated the link between the three constructs of sustainability: economic and environmental, economic and social, environmental and social;

5) Economic performance information is crucial in judging the growth and performance of a corporation by both 
internal and external stakeholders.

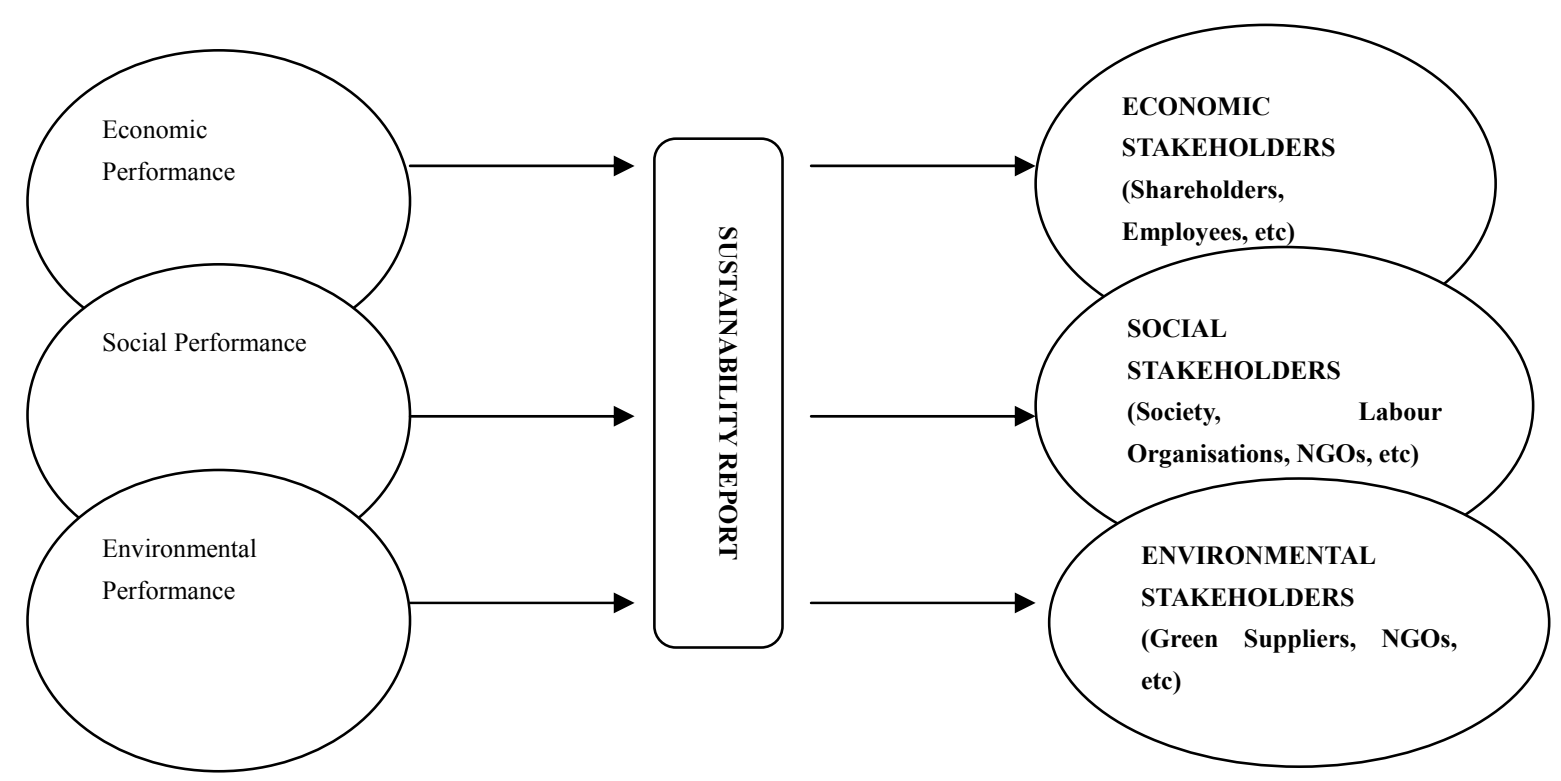

Figure 3. Postulating the link between sustainability reports and stakeholder management

\section{Recommendations}

1) A necessary first step to the practice of corporate sustainability is the identification of Key Social and Environmental Performance Indicators. This would facilitate the integration of performance across the three dimensions into corporate core objectives and strategic values and also enable the ease of quantification of these variables. The following steps could be adopted to aid management in identifying key social and environmental performance indicators:

a) Identify corporate objectives that guide the business;

b) Set up a corporate Environmental Management System to guide environmental performance management;

c) Set up a corporate Social Management System to guide social performance management;

d) The systems described in (2) and (3) should be linked to the Financial Accounting System to enable the quantification of social and environmental impact areas;

e) Link the systems (EMS and SMS) to the corporate Management Information System in order to provide management with information relevant in judging environmental and social; and also, facilitate target setting for controlling environmental and social impacts.

2) Corporate organizations should adopt and establish Social and Environmental Information Systems, to serve as inputs to the corporate management information system in order to provide management with relevant and timely information on social and environmental performance areas, for disclosing to stakeholders information for judging corporate behavior.

3) Standard setting bodies should develop more specific local standards guiding measurement and disclosure of sustainability practices, such as those in the UK and Europe. This would serve as a guide to adopters on variables for measurement and disclosure.

4) Recently accounting scholars have proposed a framework for Sustainability Management Accounting System (see Petcharat and Mula, 2010; Arroyo, 2008). Organizations desiring to meet performance across the three dimensions of sustainability should adopt this framework to aid the internalization of externalities (costs external to the entity).

\section{References}

Arroyo, P. (2008). The Three Dimensions of a Sustainable Management Accounting System. ASAC, 29, 23-39.

Constructing Excellence. (2004). Sustainability Accounting. Retrieved 1st November, 2012 from http://www.constructingexcellence.org.uk 
Egbunike, F. C., Eckekoba, F. N., \& Udeh, F. N. (2012). A Novel 'Stakeholder Sustainability Knowledge Management' Model: Developing linkages of stakeholder management, knowledge management and triple bottom line performance. Review of Public Administration and Management, 1(2), 227-247.

Elkington, J. (1998). Cannibals with forks: the triple bottom line of 21 st century business. British Columbia: New Society Publishers.

Fauzi, H., Svensson, G., \& Rahman, A. (2010). "Triple Bottom Line" as "Sustainable Corporate Performance": A Proposition for the Future. Sustainability, 2(5), 1345-1360. http://dx.doi.org/10.3390/su2051345

Freeman, E. R. (1984). Strategic Management: A Stakeholder Approach. Pitman, Boston.

Freeman, E. R., \& Reed, D. L. (1983). Stockholders and Stakeholders: A New Perspective on Corporate Governance. California Management Review, 25(3), 88-106. http://dx.doi.org/10.2307/41165018

Global Reporting Inititaive (GRI). (2011). Sustainability Reporting Guidelines (Version 3.1). Retrieved 6th November, 2013 from http://www.globalreporting.org

Herciu, M., Ogrean, C., \& Belascu, L. (2011). A Behavioural Model of Management - Synergy between Triple Bottom Line and Knowledge Management. World Journal of Social Sciences, 1(3), 172-180.

Hubbard, G. (2006). Sustainable organisation performance: Towards a practical measurement system. Monash Business Review, 2(3), 1-19.

IFAC. (2006). Annual Report. Retrieved $15^{\text {th }}$ January, 2013 from http://www.ifac.org/publications-resources/2006-ifac-annual-report

Jasch, C., \& Lavicka, A. (2005). Pilot project on sustainability management accounting with the Styrian automobile cluster. Journal of Cleaner production, 1-14.

Jasch, C., \& Stasiskiene, Z. (2005). From Environmental Management Accounting to Sustainability Management Accounting. Environmental research, engineering and management, 34(4), 77-88.

Mark-Herbert, C., Rotter, J., \& Pakseresht, A. (2010). A triple bottom line to ensure Corporate Responsibility. Retrieved $15^{\text {th }} \quad$ January $2013 \quad$ from http://cemusstudent.se/wp-content/uploads/2012/11/Corporate-perspectives-on-CR-Timeless-Cityland-withreference-2011+.pdf

Osisioma, B. C. (2010). Global Financial Crisis: Impact on the Changing Face of Accountancy Profession. Frontier Lecture Series 001, Department of Accountancy: Nnamdi Azikiwe University.

Perrini, F., \& Tencati, A. (2006). Sustainability and Stakeholder Management: the Need for New Corporate Performance Evaluation and Reporting Systems. Business Strategy and the Environment, 15, 296-308. http://dx.doi.org/10.1002/bse.538

Petcharat, N., \& Mula, J. M. (2010). Sustainability Management Accounting System (SMAS): towards a conceptual design for the manufacturing industry. Proceedings of the 2010 AFAANZ Conference.

PriceWaterHouseCoopers (PWC). (2011). Sustainability Reporting Publication. Retrieved 1st November, 2011

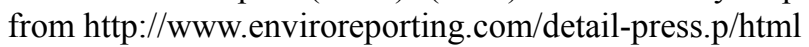

Sani, A. A., \& Allahverdizadeh, M. (2012). Target and Kaizen Costing. Retrieved from http://www.waset.ac.nz/journals/waset/v62/v62-10.pdf

The Sigma Project. (2003). The Sigma Toolkit. Retrieved $3^{\text {rd }}$ February, 2013 from http://www.projectsigma.com

Tregidga, H., Milne, M., \& Kearins, K. (2010). (Re)Presenting 'Sustainable Organizations': A New Discursive Identity. $\quad$ Retrieved 6th $\quad$ February, 2013 from http://www.acis.canterbury.ac.nz/documents/Markus_Milne_Research_Programmes/Re_Presenting_Sustain able_Organizations.pdf 